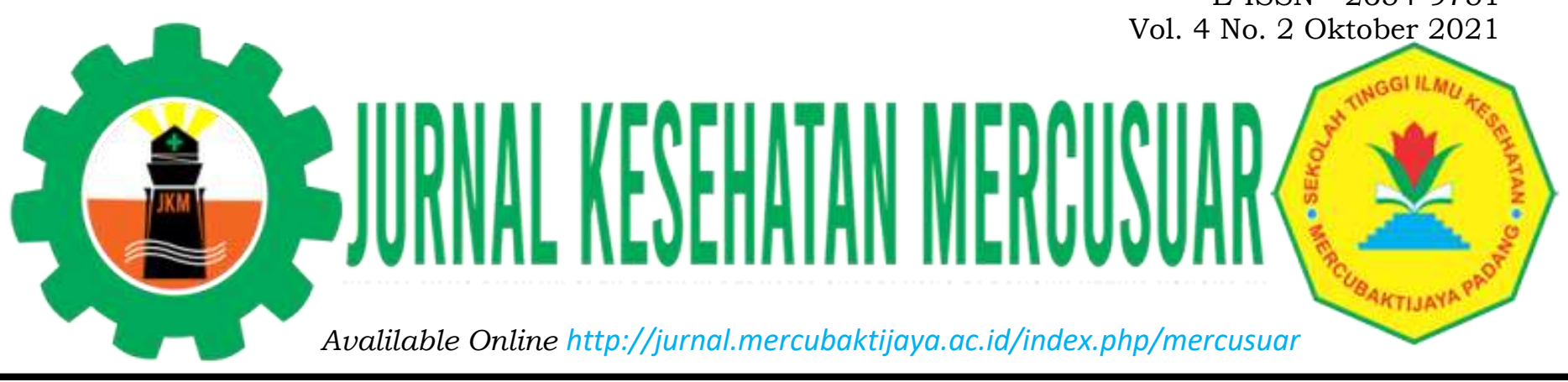

\title{
PENGARUH PENDIDIKAN KESEHATAN DAN KONSUMSI AIR REBUSAN DAUN SALAM TERHADAP PENGENDALIAN ASAM URAT
}

\author{
Sri Wahyuni Adriani ${ }^{1}$, Mardiana Firdausi ${ }^{2}$, Devry Eka Wahyudi ${ }^{3}$, Fitri Dwi Anggraeni ${ }^{4}$, \\ Gunawan Tri Sutrisno ${ }^{5}$, Zehrotul Jannah ${ }^{6}$, Muhammad Nuryasin ${ }^{7}$ \\ ${ }^{1,2}$ Fakultas Ilmu Kesehatan, Universitas Muhammadiyah Jember \\ *Email Korespondensi : sriwahyuni@unmuhjember.ac.id
}

\begin{abstract}
Healthy lifestyle is an indicator and influence on health problems. Self-management in dealing with this must be done productively. When uric acid is produced in excess and the processing of uric acid is decreased, uric acid levels in the blood are higher. To overcome this, non-pharmacological treatment can be done by consuming boiled water of bay leaves. In addition, health education is also needed. Health education is one of the effective nursing interventions to increase awareness and knowledge. This study aims to determine the effect of uric acid health education and consumption of bay leaf boiled water to control gout. The research method used is pre-experimental design with pretest-posttest design approach. The population in this study were 52 respondents with gout. The sampling method used was simple random sampling and the Wilcoxon test statistic was used. The sample in this study were 22 respondents who were determined using the slovin formula. The results showed that the uric acid level of the respondents before consuming the boiled water of bay leaves was $10 \mathrm{mg} / \mathrm{dL}$, while after consuming the boiled water, the bay leaf became $6 \mathrm{mg} / \mathrm{dL}$. Where this bay leaf boiled water can be consumed $2 x$ in a week as much as approximately 1 cup in one consumption. While the results of the pretest and posttest of health education showed a p-value of 0.001, which is less than 0.05. In other words, health education and consumption of bay leaf boiled water can effectively reduce uric acid levels. This research is recommended for all people with gout because this intervention is easy to do, materials and tools can be easily accessed, cost-effective so that it can be applied independently.
\end{abstract}

Keywords: Bay leaf stew water, Gout arthritis, Health education

\section{ABSTRAK}

Pola hidup sehat menjadi indikator dan pengaruh terhadap masalah kesehatan. Manajemen diri dalam menyikapi hal tersebut harus dilakukan secara produktif. Ketika asam urat diproduksi berlebihan dan pengolahan asam urat menurun, kadar asam urat dalam darah lebih tinggi. Untuk mengatasi hal tersebut, dapat dilakukan pengobatan nonfarmakologis dengan mengonsumsi air rebusan daun salam. Selain itu, pendidikan kesehatan juga diperlukan. Pendidikan kesehatan menjadi salah satu intervensi keperawatan yang efektif untuk meningkatkan kesadaran dan pengetahuan. Penelitian ini bertujuan untuk mengetahui pengaruh pendidikan kesehatan asam urat dan konsumsi air rebusan daun salam untuk mengendalikan asam urat. Metode penelitian yang digunakan adalah pre-experimental design dengan pendekatan pretestposttest design. Populasi dalam penelitian ini adalah 52 responden penderita asam urat. Metode 
Sri Wahyuni Adriani ${ }^{1}$, Mardiana Firdausi ${ }^{2}$, Devry Eka Wahyudi ${ }^{3}$, Fitri Dwi Anggraeni ${ }^{4}$, Gunawan Tri Sutrisno ${ }^{5}$, Zehrotul Jannah ${ }^{6}$, Muhammad Nuryasin ${ }^{7}$ | Pengaruh Pendidikan Kesehatan Dan Konsumsi Air Rebusan Daun Salam Terhadap Pengendalian Asam Urat

pengambilan sampel menggunakan simple random sampling dan menggunakan uji statistik uji Wilcoxon. Sampel dalam penelitian ini adalah 22 responden yang ditetapkan menggunakan rumus Slovin. Hasil penelitian menunjukkan kadar asam urat responden sebelum mengkonsumsi air rebusan daun salam yaitu $10 \mathrm{mg} / \mathrm{dL}$ sedangkan setelah mengkonsumsi air rebusan daun salam menjadi $6 \mathrm{mg} / \mathrm{dL}$. Dimana air rebusan daun salam ini dikonsumsi 2x dalam satu minggu sebanyak kurang lebih 1 gelas dalam sekali konsumsi. Sedangkan hasil pretest dan posttest pendidikan kesehatan menunjukkan nilai p-value 0,001 , yaitu kurang dari 0,05. Dengan kata lain, pendidikan kesehatan dan konsumsi air rebusan daun salam efektif dapat menurunkan kadar asam urat. Penelitian ini direkomendasikan untuk seluruh masyarakat penderita asam urat karena intervensi ini mudah dilakukan, bahan dan alat dapat dijangkau, hemat biaya sehingga dapat di terapkan secara mandiri.

Kata Kunci : Air rebusan daun salam, Asam urat, Pendidikan kesehatan

\section{PENDAHULUAN}

Asam urat atau gout arthritis masih menjadi masalah kesehatan pada dewasa hingga lansia yang mengganggu aktivitas. Terdapat dua pembagian gout arthritis, yaitu fase akut dan fase kronis. Asam urat fase akut merupakan penyakit dengan insiden tertinggi pada orang dewasa dan orang tua. Deteksi dini dan intervensi gejala asam urat akan menghasilkan efek prediksi lebih baik. Pada stadium kronis, arthritis gout dapat menyebabkan kerusakan sendi yang parah dan beresiko pada penyakit ginjal. Kondisi ini disebabkan karena tidak segeranya diberikan penanganan awal pada penderita Gout Arthritis saat terdeteksi tanda gejala (M. Arifki Zainaro et al., 2021). Respon tubuh terhadap gejala gout adalah nyeri sendi. Rasa sakit ini disebabkan oleh tingginya konsentrasi purin dalam darah. Gejala yang menyakitkan ini terjadi pada malam hari sebelum tidur dan ketika bangun di pagi hari. Berlangsung 4 hingga 11 hari, keluhan tersebut menjadikan hal yang tidak nyaman bagi penderita gout arthritis (Sari, Johan, Yuswanto, \& Fatmasari, 2020).

Beberapa cara yang digunakan dalam pengendalian untuk mencegah terjadinya peningkatan kadar purin yaitu dengan mengatur pola makan yang sesuai, banyak mengkonsumsi vitamin dan mineral, pengendalian stres, menghindari dan berhenti merokok serta melakukan terapi baik farmakologi maupun non farmakologi.
Pengobatan farmakologi bisa dengan mengkonsumsi obat yang telah diresepkan oleh dokter. Sedangkan non farmakologi dapat menggunakan pengobatan herbal (Ndede, Oroh, \& Bidjuni, 2019). Tanaman salam (Syzygium Polyanthum Wight) dapat digunakan sebagai pengobatan herbal antihiperurisemia.

Bagian tumbuhan yang dapat menahan hiperurisemia adalah daunnya. Kandungan dalam tanaman salam ini yaitu senyawa seperti tanin, flavonoid, alkaloid dan minyak atsiri terdiri dari sitrat dan eugenol yang ditemukan dalam daunnya. Daun salam dapat memproduksi lebih banyak urin (diuretik) ini akan menurunkan kadar asam urat dalam darah (Sari et al., 2020).

Menurut penelitian yang dilakukan di Padang, penggunaan rebusan daun salam dapat menurunkan kadar asam urat dalam darah, yang menandakan bahwa mengkonsumsi rebusan daun salam memiliki efek yang tepat dalam menurunkan kadar asam urat dalam darah. Intervensi ini telah terbukti membantu mengurangi kadar asam urat dalam darah klien dengan artritis gout. Prevalensi gout arthritis di seluruh dunia adalah 34,2\% (WHO, 2017). Artritis gout sering terjadi di negara maju. Namun angka kejadian gout arthritis semakin meningkat tidak hanya di negara maju, tetapi juga di negara berkembang salah satunya Indonesia. (Kumar, B \& Linert, 2016). Fenomena gout arthritis semakin meningkat 
Sri Wahyuni Adriani ${ }^{1}$, Mardiana Firdausi ${ }^{2}$, Devry Eka Wahyudi ${ }^{3}$, Fitri Dwi Anggraeni ${ }^{4}$, Gunawan Tri Sutrisno ${ }^{5}$, Zehrotul Jannah ${ }^{6}$, Muhammad Nuryasin ${ }^{7} \mid$ Pengaruh Pendidikan Kesehatan Dan

Konsumsi Air Rebusan Daun Salam Terhadap Pengendalian Asam Urat

di Indonesia. Angka kejadian artritis gout tahun 2013 sebesar 11,9\% (Kementrian Kesehatan, 2018).

Pada penelitian yang dilakukan di Jember khususnya Wilayah Kecamatan Umbulsari didapatkan hasil dari masalah yang muncul pada dewasa dengan masalah kesehatan yaitu Asma 1 warga $(1,7 \%)$, TBC 1 warga $(1,7 \%)$, Hipertensi 6 warga (10\%), Asama urat 14 warga $(23,3 \%)$, Lambung 2 warga $(3,3 \%)$, Kolesterol 4 warga $(6,7 \%)$, dan Tidak ada keluhan 32 warga $(53,3 \%)$. Dari hasil data tersebut didapatkan warga dewasa yang memiliki masalah kesehatan terbanyak pada penyakit Asam urat dengan 14 warga dewasa $(23,3 \%)$ dan 8 dari lansia. Gout Artritis sering diderita oleh laki-laki maupun perempuan pada usia diatas 30 tahun. Pada saat yang sama, kejadian gout arthritis adalah yang tertinggi di antara orang tua. Kejadian ini berhubungan dengan penurunan fungsi muskuloskeletal dan penurunan metabolisme purin. Diperkirakan 8,5\% gout dan 4.444 kasus arthritis menyerang pada wanita dan $6,1 \%$ menyerang pada pria (Kementrian Kesehatan RI, 2018).

Salah satu upaya untuk menyelesaikan masalah kesehatan terutama pengendalian Asam urat tinggi dalam darah adalah dengan memberikan intervensi keperawatan, intervensi tersebut berdasarkan penelitian (Cumayunaro, 2017) yang berjudul "Rebusan Daun Salam Untuk Nyeri Arthritis Gout Di Puskesmas Andalas Padang" menunjukkan hasil terhadap intensitas nyeri setelah mengkonsumsi air rebusan daun salam terjadi penurunan. Nyeri yang dialami rata-rata sebelum minum air rebusan daun salam tingkat nyeri 6,08 yaitu nyeri sedang. Sementara itu, setelah menerima air rebusan daun salam, nyeri berkurang menjadi nyeri ringan, dan tingkat nyeri adalah 3,33.

Peneliti akan memberikan implementasi serta mengajarkan responden terkait upaya penurunan kadar asam urat didalam darah. Dengan pendidikan kesehatan serta pemberian konsumsi air rebusan daun salam untuk mengurangi kadar purin dalam darah.

\section{METODE PENELITIAN}

Metode penelitian yang digunakan dalam penelitian ini adalah penelitian preexperimental design dengan menggunakan metode pretest-posttest design dengan uji Wilcoxon, yang bertujuan untuk mengetahui perubahan kadar asam urat sebelum dan sesudah intervensi, serta tingkat pengetahuan, sikap dan perilaku sebelum dan sesudah intervensi. Populasi penelitian ini adalah penderita asam urat sejumlah 52 responden di Wilayah Kecamatan Umbulsari. Sampel diambil dengan menggunakan teknik simple random sampling menggunakan rumus Slovin. Penelitian ini telah mendapatkan persetujuan layak etik dari komisi etik penelitian kesehatan (KEPK) Fakultas Ilmu Kesehatan Universitas Muhammadiyah Jember dengan nomor 315/KEPK/FIKES/III/2021.

Penelitian ini juga menetapkan beberapa kriteria inklusi yaitu: 1) Didiagnosis asam urat kurang lebih 6 bulan; 2) Usia >20 tahun; 3) Mampu berkomunikasi dengan baik dan kooperatif; 4) Memiliki kesadaran penuh. Adapun proses pengambilan sampel terdapat pada gambar 1. Alat yang digunakan adalah angket dan formulir observasi. Instrumen penelitian diadopsi dari penelitian (Ndede et al., 2019) yang dimodifikasi oleh peneliti sesuai bahasa dan kondisi ditempat penelitian. Instrumen kuesioner terdiri dari: 1) data kependudukan; 2) data khusus. Kuesioner data kependudukan meliputi nama (huruf inisial), jenis kelamin, umur, pekerjaan, lama menderita asam urat, dan riwayat keluarga dengan asam urat. Kuesioner data khusus terdiri dari 15 soal dimana masing-masing 5 
Sri Wahyuni Adriani ${ }^{1}$, Mardiana Firdausi ${ }^{2}$, Devry Eka Wahyudi ${ }^{3}$, Fitri Dwi Anggraeni ${ }^{4}$, Gunawan Tri Sutrisno ${ }^{5}$, Zehrotul Jannah ${ }^{6}$, Muhammad Nuryasin ${ }^{7} \mid$ Pengaruh Pendidikan Kesehatan Dan Konsumsi Air Rebusan Daun Salam Terhadap Pengendalian Asam Urat

soal terbagi menjadi kognitif, afektif, dan psikomotor. Sedangkan pada lembar observasi dilakukan observasi hal ini terkait dengan kadar asam urat dalam darah sebelum dan sesudah minum air rebusan daun salam. Daun salam yang digunakan adalah daun segar sebanyak 10 hingga 25 lembar kemudian direbus dengan 3 gelas air kemudian tunggu hingga mendidih atau kurang lebih tinggal 1 gelas atau kurang lebih 200cc. Air rebusan ini dapat dikonsumsi selagi hangat dan dikonsumsi sebanyak 2x dalam satu minggu. Proses evaluasi dilakukan setelah responden mengkonsumsi air rebusan daun salam selama 2 minggu, kemudian dilakukan pemeriksaan kadar asam urat menggunakan alat yang dibawa oleh peneliti sendiri.

Klien Asam Urat ( $\mathrm{n}=52)$
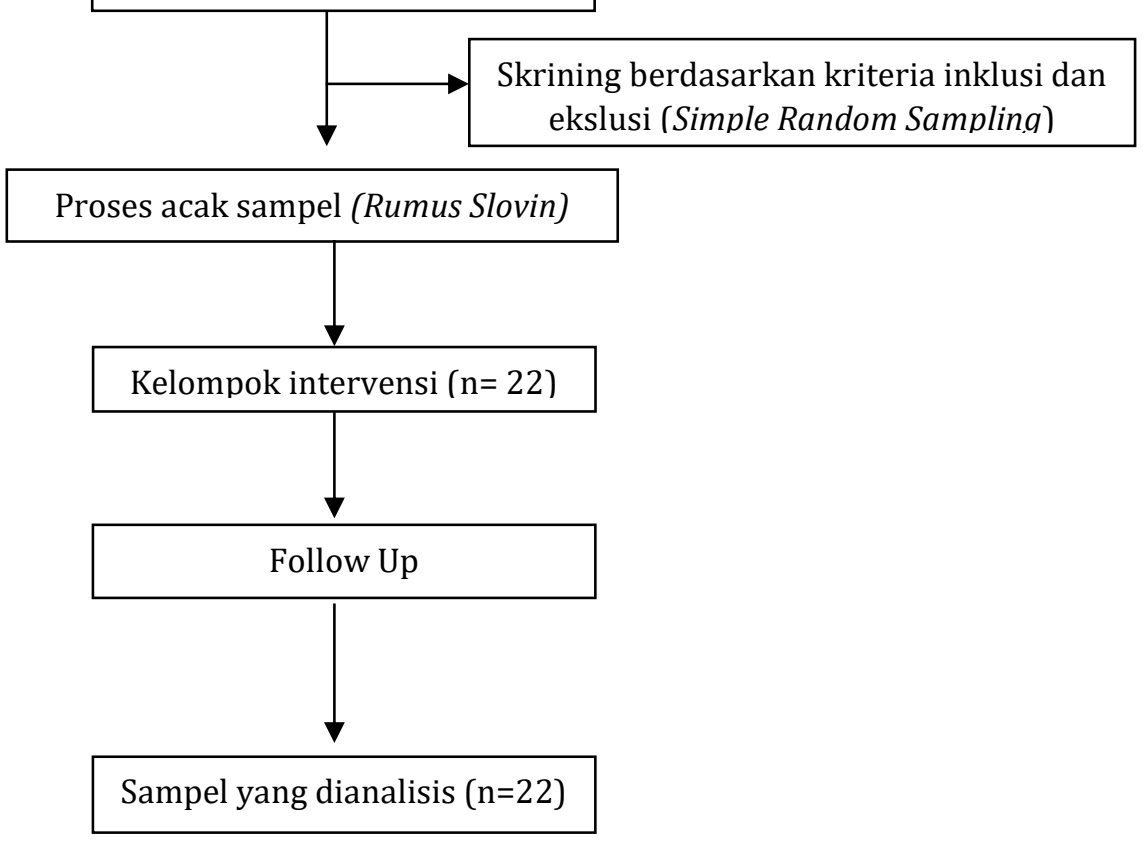

Gambar 1. Proses Pemilihan Sampel

\section{HASIL DAN PEMBAHASAN}

Data yang ditunjukkan dalam hasil penelitian menunjukkan bahwa data di analisis dalam bentuk tabel berupa data demografi dan data khusus, serta terdapat uraian secara singkat interpretasi hasil data dari masing-masing tabel. 
Sri Wahyuni Adriani ${ }^{1}$, Mardiana Firdausi ${ }^{2}$, Devry Eka Wahyudi ${ }^{3}$, Fitri Dwi Anggraeni ${ }^{4}$, Gunawan Tri Sutrisno ${ }^{5}$, Zehrotul Jannah ${ }^{6}$, Muhammad Nuryasin ${ }^{7}$ | Pengaruh Pendidikan Kesehatan Dan Konsumsi Air Rebusan Daun Salam Terhadap Pengendalian Asam Urat

\section{Tabel 1. Karakteristik Responden Berdasarkan Data Demografi}

\begin{tabular}{llcc}
\hline \multicolumn{1}{c}{ Variabel } & & n (jumlah responden) & Persentase (\%) \\
\hline Jenis Kelamin & Laki-laki & 14 & 63,6 \\
\multirow{2}{*}{ Usia } & Perempuan & 8 & 36,4 \\
& $30-40$ tahun & 2 & 9,1 \\
& $41-50$ tahun & 5 & 22,7 \\
& $51-60$ tahun & 10 & 45,5 \\
Pekerjaan & $61-70$ tahun & 5 & 22,7 \\
& Petani & 13 & 59,1 \\
\multirow{4}{*}{ Waktu Menderita } & IRT & 3 & 13,6 \\
Asam Urat & Wiraswasta & 6 & 27,3 \\
Riwayat Keluarga & $>1$ tahun & 12 & 54,5 \\
Menderita Asam Urat & Tidak ada & 10 & 45,5 \\
& Ada & 16 & 72,7 \\
\end{tabular}

Berdasarkan Tabel 1, karakteristik gender responden berjenis kelamin laki-laki dengan usia paling banyak yaitu pada rentang 51-60 tahun. Pekerjaan mayoritas yaitu petani. Sedangkan lama menderita asam urat yaitu masih kurang dari 1 tahun, artinya asam urat terjadi masih dalam waktu dekat dan paling banyak tidak ada keluarga yang menderita penyakit asam urat.

Tabel 2. Data Khusus Pengetahuan, Sikap, Prilaku dan Kadar Asam Urat Responden Sebelum dan Sesudah Pendidikan Kesehatan

\begin{tabular}{lccccc}
\hline $\begin{array}{l}\text { Pendidikan } \\
\text { Kesehatan }\end{array}$ & Mean & Std. Deviasi & $\begin{array}{c}\text { Nilai } \\
\text { Minimal }\end{array}$ & $\begin{array}{c}\text { Nilai } \\
\text { Maksimal }\end{array}$ & p-value \\
\hline $\begin{array}{l}\text { Pengetahuan } \\
\quad \text { Pre-Test }\end{array}$ & 7,55 & 1,22 & 5 & 9 & 0,000 \\
$\quad \begin{array}{l}\text { Post-Test } \\
\text { Sikap }\end{array}$ & 9,14 & 1,20 & 7 & 10 & \\
$\quad$ Pre-Test & 10,9 & 2,77 & 5 & 15 & 0,000 \\
$\quad$ Post-Test & 15,9 & 2,06 & 13 & 20 & \\
$\begin{array}{l}\text { Perilaku } \\
\text { Pre - Test }\end{array}$ & 9,1 & 3,07 & 5 & 15 & 0,001 \\
$\quad$ Post-Test & 14,0 & 3,33 & 20 & 20 & \\
\hline
\end{tabular}


Sri Wahyuni Adriani ${ }^{1}$, Mardiana Firdausi ${ }^{2}$, Devry Eka Wahyudi ${ }^{3}$, Fitri Dwi Anggraeni ${ }^{4}$, Gunawan Tri

Sutrisno ${ }^{5}$, Zehrotul Jannah ${ }^{6}$, Muhammad Nuryasin ${ }^{7} \mid$ Pengaruh Pendidikan Kesehatan Dan

Konsumsi Air Rebusan Daun Salam Terhadap Pengendalian Asam Urat

Tabel 3. Data Hasil Pengukuran Kadar Asam Urat Dalam Darah Sebelum Dan Sesudah Konsumsi Air Rebusan Daun Salam

\begin{tabular}{cccccc}
\hline Kadar Asam Urat & Mean & Std. Deviasi & $\begin{array}{c}\text { Nilai } \\
\text { Minimal }\end{array}$ & $\begin{array}{c}\text { Nilai } \\
\text { Maksimal }\end{array}$ & p-value \\
\hline Pre - Test & 8,93 & 1,05 & 7,2 & 10,6 & 0,000 \\
Post - Test & 5,44 & 0,76 & 4,3 & 6,9 & \\
\hline
\end{tabular}

Tabel 2 dan 3 menunjukkan bahwa terdapat perbedaan yang relevan dari pengetahuan, sikap, prilaku dan kadar asam urat darah sebelum dan sesudah diberikan pendidikan kesehatan dan konsumsi air rebusan daun salam. Dengan demikian pendidikan kesehatan tersampaikan dengan baik kepada responden. Responden juga memahami dengan baik dan mampu mengubah prilaku dalam upaya pengendalian asam urat. Responden juga dapat menerapkan kebiasaan untuk mengkonsumsi air rebusan daun salam sesuai anjuran yang telah dijelaskan dengan baik. Sehingga, selama dilakukan intervensi rebusan daun salam memiliki efek meredakan nilai asam urat dalam darah.

\section{PEMBAHASAN}

Daun salam (Syzygium polyantha) adalah sejenis daun yang sangat mudah ditemui di lingkungan rumah masyarakat pedesaan. Daun salam juga hampir selalu digunakan sebagai penyedap rasa masakan Indonesia. Selain digunakan sebagai penyedap masakan, daun salam juga dapat dikonsumsi sebagai minuman. Minuman daun salam atau biasa disebut air rebusan daun salam dapat diekstrak dari daun segar atau daun kering. Daun ini dipercaya dapat digunakan sebagai obat untuk tekanan darah tinggi, meredakan nyeri akibat asam urat, mengurangi kadar kolesterol, dan mengobati diare (Savitri, 2016). Penggunaan daun salam ini tidak sembarangan digunakan, ada beberapa teknik yang harus dilakukan untuk menjaga kadar khasiat dari daun tersebut maka dari itu perlu dilakukan sebuah penelitian untuk mengetahui pengetahuan setiap masyarakat terkait kebermanfaatan daun salam. Pengetahuan seseorang berkaitan dengan tingkat pendidikannya. Orang yang berpendidikan tinggi memiliki pengetahuan yang lebih banyak, tetapi bukan berarti orang dengan tingkat pendidikan yang rendah tidak memiliki pengetahuan sama sekali. Karena pengetahuan diperoleh tidak hanya melalui pendidikan, tetapi juga melalui pengalaman.

Penelitian yang telah dilakukan ini menggunakan penilaian pretest dan postest pada pendidikan kesehatan menunjukkan adanya peningkatan pengetahuan. Dibuktikan dari hasil Uji statistik $u j i$ Wilcoxon menunjukkan bahwa diantara 22 responden diperoleh nilai p-value 0,000 ditinjau dari pengetahuan (Asymp. Sig 2 tails) yang artinya pendidikan kesehatan mempengaruhi tingkat pengetahuan pada responden. Sesuai definisi yang dikemukakan Allport bahwa setiap kesiapan seseorang dalam menerima ataupun menerapkan sesuatu dilihat dari sikap. Sikap sangat mempengaruhi proses berlangsungnya sebuah intervensi yang akan diberikan (Azwar S, 2013). Sikap yang dimiliki tidak terlepas dari pengetahuan, dimana mayoritas responden tidak mengetahui cara mengendalikan asam urat salah satunya dengan rutin melakukan 
Sri Wahyuni Adriani ${ }^{1}$, Mardiana Firdausi ${ }^{2}$, Devry Eka Wahyudi ${ }^{3}$, Fitri Dwi Anggraeni ${ }^{4}$, Gunawan Tri

Sutrisno ${ }^{5}$, Zehrotul Jannah ${ }^{6}$, Muhammad Nuryasin ${ }^{7} \mid$ Pengaruh Pendidikan Kesehatan Dan

Konsumsi Air Rebusan Daun Salam Terhadap Pengendalian Asam Urat

pengecekan kadar asam urat minimal satu bulan sekali, sehingga tidak dilakukannya dan cenderung menganggap asam urat adalah hal biasa dan tidak terlalu mengkhawatirkan kondisi kesehatannya. Hal ini dibuktikan dengan sikap mereka yang masih tidak menghiraukan kesehatannya dan tidak melakukan diet pada makanan pemicu asam urat. Disebabkan karena rendahnya pengetahuan dan keyakinan responden yang masih rendah (Chandratre et al., 2018).

Berdasarkan penelitian yang telah dilakukan hasil dari pretest dan postest pada aspek sikap yaitu adanya peningkatan setelah diberikan pendidikan kesehatan. Dibuktikan dengan Uji Wilcoxon menunjukkan dari 22 responden p-value sebesar 0,000. Artinya ada pengaruh pendidikan kesehatan dengan sikap untuk mengendalikan asam urat. Perilaku yang ditendesikan dalam penelitian ini adalah cara responden dalam mengendalikan asam urat agar tidak semakin parah. Perilaku pengendalian yang dilakukan meliputi diet makanan pemicu asam urat, melakukan olahraga atau aktifitas fisik, mengkonsumsi obat-obatan dengan rutin sesuai resep dokter maupun mengkonsumsi obat-obatan herbal atau tradisional (Chandratre et al., 2018).

Berdasarkan penelitian yang telah peneliti lakukan tentang upaya pengendalian asam urat didapatkan bahwa perilaku pengendalian meningkat setelah diberikan pendidikan kesehatan. Dibuktikan dengan hasil uji yaitu Uji Wilcoxon menunjukkan bahwa pada 22 responden diperoleh nilai $\mathrm{P}$ sebesar 0,001 ditinjau dari perilaku, artinya pendidikan kesehatan meningkatkan perilaku pengendalian asam urat.

Pendidikan kesehatan menjadi salah satu pilihan edukasi yang tepat untuk memberikan penjelasan secara langsung terhadap upaya promosi kesehatan. Salah satunya dalam pengendalian asam urat. Sebelum diberikan sebuah intervensi, pendidikan kesehatan akan diberikan terlebih dahulu agar tidak terjadi disinformasi dan intervensi dapat diterima dengan baik oleh masyarakat (Nuranti, Maimaznah, \& Anggraini, 2020).

Selain intervensi yang diberikan berupa pendidikan kesehatan, intervensi lain untuk pengendalian asam urat adalah dengan minum air rebusan daun salam. Daun salam menjadi tanaman obat, digunakan untuk menahan peningkatan kadar asam urat darah untuk menurunkan kadar asam urat. Daun salam dapat meningkatkan pengeluaran urin (diuretik) untuk menurunkan asam urat dalam darah. Saat asam urat turun, rasa sakit yang dialami penderita berangsurangsur berkurang (Djohari et al., 2015).

Hal ini dapat diuji dengan mengukur kadar asam urat sebelum dan sesudah minum air rebusan. Rata-rata kadar asam urat sebelum minum air rebusan adalah 8,9 $\mathrm{mg} / \mathrm{dL}$, rata-rata kadar asam urat setelah minum air rebusan turun menjadi $5,4 \mathrm{mg} / \mathrm{dL}$. Artinya jika dikonsumsi secara rutin, air rebusan daun salam dapat meredakan nilai asam urat.

Hasil penelitian ini konsisten dengan penelitian (Ningtiyas \& Ramadhian, 2016) Salah satu tanaman yang dipercaya dapat membantu menurunkan nilai asam urat dalam darah adalah daun salam (Syzygium polyanthum). Penyebab asam urat tinggi adalah pola makan. Makan makanan tinggi purin yang tidak seimbang akan meningkatkan kadar purin dalam darah. Oleh karena itu, untuk mengendalikannya dengan mengonsumsi bahan obat, air rebusan daun salam terbukti penting meredakan nilai purin dalam darah.

Selain itu penelitian yag dilakukan oleh Aryani, Sartagus, \& Surakarta, (2020) berdasarkan uji t-test dengan paired test sebagai berikut: ada pengaruh kadar asam urat menurun sebelum dan sesudah minum air daun salam. Artinya responden yang 
Sri Wahyuni Adriani ${ }^{1}$, Mardiana Firdausi ${ }^{2}$, Devry Eka Wahyudi ${ }^{3}$, Fitri Dwi Anggraeni ${ }^{4}$, Gunawan Tri

Sutrisno ${ }^{5}$, Zehrotul Jannah ${ }^{6}$, Muhammad Nuryasin ${ }^{7} \mid$ Pengaruh Pendidikan Kesehatan Dan

Konsumsi Air Rebusan Daun Salam Terhadap Pengendalian Asam Urat

menderita asam urat dengan meminum air salam akan dapat menurunkan kadar asam urat darah. Penelitian sebelumnya yang dilakukan di Padang juga menunjukkan kadar asam urat akan turun setelah mengkonsumsi rebusan daun salam. Daun salam yang digunakan sebanyak 10 hingga 25 lembar dan air 3 gelas tunggu sampai airnya menjadi 1 gelas. Jadi bisa diminum selagi hangat, kemudian dapat dikonsumsi 2x dalam satu minggu (Febrianti \& Mira, 2018).

Penelitian yang dilakukan oleh $\mathrm{M}$. Arifki Zainaro (2021) Penderita asam urat di desa Gunung Agung minum air rebusan daun salam dan kadar asam urat darahnya turun. Dengan ini, rebusan air daun salam secara efektif dapat menurunkan kadar asam urat. Menurut penelitian yang Vechya et al., (2019) "Pengaruh Pemberian Rebusan Daun Salam terhadap Penurunan Kadar Asam Urat Pada Penderita Gout Artritis Di Wilayah Kerja Puskesmas Ranotana Weru" menunjukkan efektifnya pemberian air rebusan daun salam kepada pasien asam urat di Wilayah Kerja Puskesmas Weru Manado, dengan $p$-value 0,000 .

Penelitian ini juga sejalan dengan penelitian oleh A rhiatma, Rosita, Lestariningsih (2017) yang berjudul "Hubungan Antara Pengetahuan Tentang Gout Artritis Terhadap Perilaku Pencegahan Gout Artritis Pada Lansia" menyatakan tingkat kesadaran masyarakat terkait pencegahan dan pengendalian penyakit asam urat, semakin tinggi pengetahuan akan semakin tinggi pula prilaku pencegahan yang dilakukan masyarakat begitupun sebaliknya. Sedangkan, Menurut penelitian (Sari et al., 2020) yang berjudul "Complementary Nursing Intervention of Acupressure and Bay Leaf Extract (Syzygium polyanthum) on Reducing Pain among Patients with Arthritis Gout" menjelaskan air rebusan daun salam dapat menurunkan kadar asam urat dalam darah dan meredakan nyeri pada kelompok intervensi dan kelompok kontrol.

\section{SIMPULAN}

Berdasarkan hasil penelitian dan pembahasan tentang pengaruh pendidikan kesehatan dan konsumsi air rebusan daun salam terhadap pengendalian asam urat, dapat disimpulkan bahwa penyuluhan kesehatan dan konsumsi air rebusan daun salam berpengaruh menurunkan kadar asam urat dalam darah. Serta meningkatkan kesadaran dan perilaku pengendalian asam urat.

\section{UCAPAN TERIMA KASIH}

Terimakasih kami sampaikan kepada seluruh masyarakat dalam penelitan yang telah bersedia untuk menjadi responden. Terima kasih juga kami sampaikan kepada bapak RT wilayah setempat yang memberikan izin serta mendukung kegiatan secara penuh. Sehingga menjadikan penelitian kami berjalan dengan baik dan lancar.

\section{DAFTAR PUSTAKA}

Aryani, A., Sartagus, R. A., \& Surakarta, U. S. (2020). Pengaruh Rebusan Daun Salam Terhadap Penurunan Kadar Asam Urat Pada Lansia. 4(2), 413-423.

Azwar S. (2013). Sikap Manusia:: Teori dan

Pengukurannya. Yogyakarta: Pustaka Pelajar.

Chandratre, P., Mallen, C., Richardson, J., Muller, S., Hider, S., Rome, K., ... Roddy, E. (2018). Health-related quality of life in gout in primary care: Baseline findings from a cohort study. Seminars in Arthritis and Rheumatism, 48(1), 61-69.

Cumayunaro, A. (2017). Rebusan Daun Salam Untuk Penurunan Kadar Asam Urat dan Intensitas Nyeri Arthritis Gout 
Sri Wahyuni Adriani ${ }^{1}$, Mardiana Firdausi ${ }^{2}$, Devry Eka Wahyudi ${ }^{3}$, Fitri Dwi Anggraeni ${ }^{4}$, Gunawan Tri

Sutrisno ${ }^{5}$, Zehrotul Jannah ${ }^{6}$, Muhammad Nuryasin ${ }^{7} \mid$ Pengaruh Pendidikan Kesehatan Dan

Konsumsi Air Rebusan Daun Salam Terhadap Pengendalian Asam Urat

di Puskesmas Andalas Padang. Menara Ilmu, XI(75), 177-181.

Djohari, M., Paramitha, R., Tinggi, S., Riau, I. F., Kamboja, J., Baru, S., ... Fajar, Y. (2015). Efektivitas Rebusan Daun Salam (Syzygium Polyanthum) Terhadap Penurunan Kadar Asam Urat Dalam Darah Mencit Putih Jantan. Pharmacy, 12(02), 176-185.

Kementrian Kesehatan RI. (2018). Profil Kesehatan Indonesia 2017. Jakarta: Kemenkes RI. Time, 6(3), 198.

Kumar, B \& Linert, P. (2016). Gout and African American reducing dispaties. Amerika: Clevaland Clinic Jurnl of Medicine.

M. Arifki Zainaro1, Pribadi, T., Djunizar, Djamaludin, Andoko, ... Rika Yulendasari. (2021). Penggunaan Daun Salam Terhadap Klien Asam Urat Untuk Menurunkan Kadar Asam Urat Di Kelurahan Gunung Agung. 4, 6.

Mira, F. (2018). Pengaruh Pemberian Rebusan Daun Salam (Syzygium Polyanthum) Terhadap Kadar Asam Urat Pada Lansia. Jurnal Penelitian dan Kajian Ilmiah, XVII(2), 22-26.

Vechya, N., Oroh, W., \& Bidjuni, H. (2019). Pengaruh Pemberian Rebusan Daun Salam Terhadap Penurunan Kadar Asam Urat Pada Penderita Gout Artritis Di Wilayah Kerja Puskesmas Ranotana
Weru. Je-journal Keperawatan $(e-K p)$, $7(1)$.

Ningtiyas, I. F., \& Ramadhian, M. R. (2016). Efektivitas Ekstrak Daun Salam untuk Menurunkan Kadar Asam Urat pada Penderita Artritis Gout. Medical Journal of Lampung University, 5(3), 105-110.

Nuranti, Z., Maimaznah, M., \& Anggraini, A. A. (2020). Pengaruh Pendidikan Kesehatan dan Pemberian Daun Salam Pada Pasien Dengan Asam Urat di Wilayah RT 10 Kelurahan Murni. Jurnal Abdimas Kesehatan (JAK), 2(1), 50.

Organization, W. H. (2017). Mental disorders fact sheets. World Health Organization. 68(1), 1-12.

Sari, N., Johan, T., Yuswanto, A., \& Fatmasari, D. (2020). Complementary nursing intervention of acupressure and bay leaf extract (Syzygium polyanthum) on reducing pain among patients with arthritis gout. International Journal of Nursing and Health Services (IJNHS), 3(6), 700708.

Savitri, A. (2016). Tanaman Ajaib Basmi Penyakit dengan TOGA (Tanaman Obat Keluarga). Pemikiran Islam di Malaysia: Sejarah dan Aliran, 7(1), 37-38. 